\title{
Impact of Domestic, Foreign, and Global Environments on International Business Decisions of Multinational Firms: A Systematic Study
}

\author{
P. S. Aithal
}

Srinivas Institute of Management Studies, Srinivas University, Mangalore - 575 001, INDIA. E-Mail: psaithal@gmail.com

Type of the Paper: Research Paper.

Type of Review: Peer Reviewed.

Indexed in: OpenAIRE.

DOI: http://dx.doi.org/10.5281/zenodo.1067103.

Google Scholar Citation: IJMTS

\section{How to Cite this Paper:}

Aithal, P. S. (2017). Impact of Domestic, Foreign, and Global Environments on International Business Decisions of Multinational Firms: A Systematic Study. International Journal of Management, Technology, and Social Sciences (IJMTS), 2(2), 93-104.

DOI: http://dx.doi.org/10.5281/zenodo.1067103.

International Journal of Management, Technology, and Social Sciences (IJMTS) A Refereed International Journal of Srinivas University, India.

(C) With Authors.

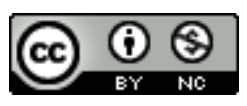

This work is licensed under a Creative Commons Attribution-Non Commercial 4.0 International License subject to proper citation to the publication source of the work.

Disclaimer: The scholarly papers as reviewed and published by the Srinivas Publications (S.P.), India are the views and opinions of their respective authors and are not the views or opinions of the SP. The SP disclaims of any harm or loss caused due to the published content to any party. 


\title{
Impact of Domestic, Foreign, and Global Environments on International Business Decisions of Multinational Firms: A Systematic Study
}

\author{
P. S. Aithal \\ Srinivas Institute of Management Studies, Srinivas University, Mangalore - 575 001, INDIA. \\ E-Mail: psaithal@gmail.com
}

\begin{abstract}
International business decisions to be taken by executive managers of multinational firms are becoming more challenging due to uncertainties in business environment which is due to fast changing and unpredictable domestic, foreign, and global environment for long term sustainability. Even though firms are cautious and take precautions while taking decisions on international investment for production and marketing, their sustainability for a long time in a given business is shaking due to continuous changes in domestic, foreign, and global business environment. This is mainly due to variations in economic conditions, political scenarios, sociocultural environment, technological breakthroughs, legal aspects and human behavioural effects on opportunities and challenges on the international business performance of multinational firms. In this paper, we have studied in brief, the various domestic, foreign, and global environmental issues which affects the multinational firm's business decisions related to international investments and marketing. The paper also discusses the impact of the domestic environment, foreign environment, and global environment on economical, political, technological, legal, and cultural issues on investment and expansion decisions of multinational corporations in general.
\end{abstract}

Keywords: International business decisions, Impact on domestic environment, Impact on foreign environment, Impact on global environment, Multinational firms.

\section{INTRODUCTION :}

The international business is considered as a positive sum game, where all the participant firms or countries are the winners in terms of benefits and hence this model of doing business by improving the modalities of it and decreasing the constraints of it became the prior policy of many country governments [1]. In order to support cross-country business by the country governments have developed many strategies and created many policies to boost the focus on international business through all possible modes of entry. But the multinational organizations which have objective of making an enhanced profit through expanding their business to many countries with the intention to gain through the globalized market to their products/services or through the globalized production to take advantage of low cost, quality resources availability and hence to become low cost players. Any firm which has plans to go for international investment for production or marketing studies the environmental factors of that business both at home country and host country. International business decisions by executive managers of multinational corporations are becoming more challenging due to uncertainties in business environment due to fast changing and unpredictable domestic, foreign, and global environment for long sustainability. Even though firms are cautious and take precautions while taking decisions on international investment for production and marketing, their sustainability for a long time in a given business is shaking due to continuous changes in domestic, foreign, and global business environment. This is mainly due to 
variations in economic conditions, political scenarios, socio-cultural environment, technological breakthroughs, legal aspects and human behavioural effects on opportunities and challenges on the international business performance of multinational corporations. In this paper, we have studied in brief, the various environmental effects both internal and external to the multinational corporations on their international business decisions related to international investments and marketing.

\section{LITERATURE REVIEW :}

A perspective on trends in multinational business and global environments is studied long back during the beginning period of globalization (1984) by Dymsza, W. A. [2] and during 1988, Welch et al, developed a conceptual paper on evolution of internationalization [3] and various strategies the firms to be followed while taking internationalization decision is published by Melin L during 1992 [4]. Riahi-Belkaoui, A. (1998) has studied the effects of the degree of internationalization on firms performance [5]. The economics of foreign direct investment incentives is studied by Blomstrom, et al, during 2003 [6] and during the year 2004, Rugman et al. [7] studied a perspective on regional and global strategies of multinational enterprises while making international investment decisions. Held, D. Et al. During the year 2000 studied the effect of Politics, economics and culture environment on global transformations [8] and Wan et al, during 2003 made an insight into home country environments, corporate diversification strategies, and firm performance [9]. An analysis on Innovation, organizational capabilities, and the born-global firm is carried out during 2004 by Knight et al. [10] and Globalisation, economic geography and the strategy of multinational enterprises through scanning home country environment is studied by Buckley et al during 2004 [11]. Many researchers studied the challenges and environmental issues related to international business investment including political environment and social \& cultural environmental challenges [12-18]. Based on literature review it is found that a detailed conceptual discussion on the effect domestic, foreign, and global environment and its impact on the decisions of Multinational firm's international business related to international investments and marketing, and can throw further light on identifying new opportunities and challenges in international business arena.

\section{OBJECTIVES:}

- The objective of this paper is multi-fold to make a conceptual discussion of the effect of external environment on the international business investment decisions.

- To develop a procedure for global environmental analysis which allows firms to take optimum decisions in international business investments for sustainable profit.

- To discuss the impact of the domestic environment, foreign environment, and global environment on investment and expansion decisions of multinational firms in general.

\section{EFFECT OF DOMESTIC ENVIRONMENTAL ISSUES ON IB DECISIONS :}

The domestic or internal environmental issues of a firm to be emerged as a multinational corporation play an important role in making managerial decisions related to investments in other countries. It is quite obvious that analysing environmental factors while making new business decisions. Environmental analysis is an essential prerequisite for strategic management decision-making and a greater emphasis is given today by almost all firms while expanding their business to outside their country boundary. Some of the major domestic or internal environmental factors which affect the international business decisions of the firms include Economic issues, Political issues, Socio-cultural issues, Technological issues, and Legal issues [19-22].

\section{(a) The Economic Issues :}

The domestic economic environment is the most important parameter for international business decisions. There are a number of general and useful indicators that are needed for assessing an economic environment in which most of the 
multinational companies operate. Some of the indicators related to economic issues of the firm as well as the home country are listed below :

- The financial capability of the firm,

- The low-cost finance availability within the country for long-term external investment,

- The type of the economy at home country,

- Low profit in local business due to high local competition,

- Possession of quality endowments in the country of global standards,

- Skilled manpower and prior global experience lead to confidence in investment.

\section{(b) Political Issues :}

The political environment in the home country also plays an important role in the international business decisions to be taken by a firm [23]. These political issues listed below may have either direct or an indirect influence on international business decisions and may also have either favorable or hostile impact on the activities of the international firm :

- Due to changes in political conditions and changes in governing political parties and their philosophy, the Country policy and State government policies towards supporting the FDI investments in other countries are changing with time.

- In case of certain specific products with possible military applications, home country political environment play an important role in firms decision-making process.

- The export of certain materials to the subsidiaries of the firm may be banned by the Home country government through enhanced tariffs, or fixing quotas, or limiting FDI flow etc.

\section{(c) Socio-Cultural Issues :}

Socio-Cultural issues in the environment of the firm in the home country deal with a set of values, beliefs, and rules, among its stakeholders in the society [24-26]. Based on the firm's experience in managing the customers with a new set of values and lifestyles in their home country, firms show interest in expanding the business to other countries where also the firm faces similar challenges.

- Since the culture and tradition of a country decide consumer behaviour in a given country, the strategies developed by the firm in the home country to handle socio-cultural issues may help its decision on international business expansion.

- The decision maker can find out the relevant similarities and differences among target markets with local market to decide what products/services may be the game changer.

- The domestic socio-cultural environment effects of the firm and its decision makers on consumer perception of products, distribution, pricing, and communications policies which can be easily tested further in international business scenarios.

(d) Technological Issues :

The domestic technological environment issue is related to the technologies developed by the firm through its efforts on R \& D and other locally available technologies to improve the features of the products and services so that they can be globally acceptable and competitive.

- The technological strength developed by the firm to innovate the products or services gives further confidence to make decisions related to international investment.

- The technological strength of the firm also gives the greatest competitive advantage to it to expand its business to many countries.

- The technological developments also against the competition and resistance from local competitor firms.

- Alternately, a firm decides to go for international business can invest more on R \& $\mathrm{D}$ and also can get access to global technology so that it can use such top technology in its own country to compete with local firms.

\section{(e) The Legal Issues :}

The legal environment in any country for international investment and market relates to the laws and regulations governing the investment decisions and conduct of business activities in that market [1, 19-22]. It may be expressed as a function of the socio-cultural, political, and ideological orientation of a country.

- Home country laws deal with the conduct of the firm in the domestic market and trade with third countries. These laws and regulations do not discriminate between domestic and 
international operators as they are designed to protect the domestic consumers, national interest, and security.

- The laws and regulations related to exporting the raw materials for international operators from the host country should be favourable investing firm.

- The home country law related to transfer of technology to other country operations should be supportive for firm's foreign operations decisions.

- The legal issues related to transfer of profit money from other countries subsidiaries to home countries also important.

\section{EFFECT OF FOREIGN ENVIRONMENTAL ISSUES ON IB DECISIONS :}

The main issues related to host country environment while making international business investment decisions are as follows:

(1) Currency Differences : Due to the differences between currencies used in different countries and also due to the fluctuation in their exchange value, there is large uncertainty in currency rate with time. Further, the firms in host country have to make all payments for their imports in host country currency which may not freely available due to the rules framed by the International Monetary Fund may sometimes limit the size of imports of raw materials from other countries and hence affects the business.

(2) Difference in Natural and Geographical Conditions: Natural endowments like fresh water, raw materials, mine and minerals, soil quality, rainfall amount, weather and temperature etc. may differ drastically between different countries. Due to such changes in natural and geographical conditions, countries and their firms may specialize themselves in the production of certain commodities with highquality and low-cost. Such specialization based high-quality low-cost products of local firms may impose challenges to the foreign firms to take investment decisions.

(3) Mobility in Factors of Production : The issues like availability of skilled labours and capital in host country for the firm's business or the possible mobility of such factors of endowment from the home country are getting importance while making the international business investment decision.

(4) Difference in Political Systems: Presently in the world, each and every country is considered as an independent political entity with its own political agenda to maintain the countries (people and firms) interest. As a result, different countries impose different types of barriers on imports and exports in the national interest. Such trade barriers may be (i) Imposition of tariffs and customs duties on imports and exports, (ii) Quantitative restrictions like quota etc., (iii) Subsidies to local firms against foreign forms, (iv) Exchange rate control, (v) Imposition of more taxes for foreign investors etc. Depending on political conditions and policies, of the country, there may be a substantial difference in the tax imposed on domestic firms and on international firms which may hinder the interest of the firms on international business investment.

(5) Difference in Legal Systems: The difference in legal systems between different countries makes the various business processes quite difficult especially due to the reason that they have to study and follow legal provisions of the two countries as regards to a particular trade.

(6) Population \& Occupation Distribution: The population and its distribution, the education level and occupational distribution also differ from country to country. This leads the availability skilled and experienced employees in foreign countries. A firm which is intended to invest in another country should study the availability of skilled workers before taking decisions related to such investment.

(7) Transportation Infrastructure : The type, availability, and the cost of transportation systems in the host country to transport the raw materials and finished products from sources to production plant and from the production plant to market also contribute the decision on expanding the business by international investment.

\section{(8) Scalability in Production:}

The increase in the scale of production gives many advantages for the firms including low unit production cost. This supports firms to 
increase their production by creating more demand. One of the methods to increase the demand for the firm's products is creating more demand for such products through expanding the market share to other countries through proper international investment decisions.

\section{(9) Differences in Production Costs:}

The cost of production of any product differs from one country to another due to various reasons which include the availability of quality natural resources, supportive geographical conditions, supportive industries, skilled employees, production in large scale, degree of automation, availability of developed technology etc. The international investment decision is strongly influenced by the cost of production in a given foreign country and the opportunity to become cost leader.

(10) Degree of Self-sufficiency: The opportunity of creating demand for its products to expand market share is the major objective of any firm while deciding on international business in a foreign country. Such opportunity of creating demand mainly depends on the degree of self-sufficiency of that foreign country and is usually, differs from country to country. Therefore, the countries which cannot produce at all or can produce only at a very high cost, are the potential host countries to attract international business investments.

\section{EFFECT OF GLOBAL ENVIRONMENTAL ISSUES ON IB DECISIONS :}

Global environmental issues can be identified and monitored with the help of a checklist based procedure that evaluates every possible favourable and unfavourable factor. In general, while analysing every factor in global environmental issues, a proper procedure has to be developed systematically to identify changes. The issues related to the global environment for international business decisions can be analysed using four steps which include Global environmental Observation, Global environmental monitoring, and Global environmental assessment, Global environmental forecasting and Assessment of global investment outcome. This procedure of global environmental analysis allows firms to take optimum decisions in international business investments.

\section{(1) Global Environmental Observation :}

The global environmental observations involve observations of specific industry segment globally to find business opportunity. Such observation based on the objective of detecting the variations in demand conditions for goods or services globally. This can be done by defining and finding trend indicators related to the factor of observation. These indicators are able to detect and measure continuously the changes in various environmental factors globally. This include :

- The changes in demand and supply conditions of a commodity in global market,

- The changes in production factors through changes in technology,

- The changes in consumer attitude and aspiration due to societal reasons,

- The changes in business models and their effect on customers buying pattern,

- The changes in economic conditions of countries globally,

- The changes in political scenario of the countries and the consequence,

- The changes in business factors due to unexpected natural calamity or man-made disasters including long-time cold war or full-fledged war,

- The changes due to trade-related agreements between a set of countries, Changes in demand factors due to better alternative products discovery,

- The changes in individual country legal systems as well as changes in global legal systems which may be due to changes in business models and strategies.

- The changes in infrastructure facilities which may make the business easy and cost effective etc.

Global environmental observation can include media scanning, product/services scanning, business model scanning, technology scanning, and Economical and political situation scanning. Media scanning is a process of examining every material published in the media such as national and international magazines, televisions, 
newspapers and other data sources. Product/services scanning consist of scanning of products/services which need /take additional features/values from the customer point of view. Global environmental observation can be done majorly through the internet as online ubiquitous scanning media to identify international business opportunities.

\section{(2) Global Environmental monitoring :}

Global environmental observation is the initial component of the global environmental analysis. After identifying critical trends and potential events during observation, the next step is called global environmental monitoring. In this stage, the identified issues and opportunities have to be repetitively observed in order to monitor the specified change indicators based on a defined purpose. Usually, the monitoring is done regularly by collecting specified data related to such event. During the observation stage, data about environmental developments are recorded, followed, evaluated and interpreted using any and relevant data collection methodology.

\section{(3) Global Environmental assessment :}

In this step of the global environmental analysis, the firm makes an assessment of possible opportunities by analysing the data. It may use various data analysis techniques available in various research methodologies. Various analysis frameworks may be also used at this stage based on their suitability [1]. Various probability factors can be included at this stage while doing the assessment of the situations identified in the previous stage of environmental monitoring. The assessment stage provides the international business trends based on various changes observed in environmental observation stage.

\section{(4) Global Environmental forecasting :}

In this stage of environmental analysis, the direction, speed, and intensity of environmental trends are predicted through environmental forecasting. The prediction for possible opportunities and threats is the focus in this stage. Forecasting based on previous and present trends in various changes in situations and the possibility of converting them into opportunities and the expected results if the available opportunities are en-cashed is the necessary objective of this stage.

Various methods like strategic foresight or scenario analysis, guessing based on luck, rule of thumb, extrapolation method for determining predicted tendencies, expert judgment, leading indicators based on identified relevant variables, surveys to collect information on future, timeseries models to know historic pattern of data and focus on measurable uncertainty, econometric systems used to model the behaviour of group of resources in a system etc. may be used at this stage.

(5) Assessment of Global Investment Outcome :

This is the last stage of global environmental analysis while making an international investment decision by the firms. In this stage, the discovered environmental trends and forecasts are reviewed to estimate the probability of their occurrence. Further, these results are analyzed to evaluate whether they represent a chance or a risk for the investment. The expected outcomes are analysed through performance analysis techniques as well as risk analysis methods. Sometimes this is also done with the help of the Issue-Impact-Matrix, an adequate instrument to evaluate and prioritize trends. The forecasted environmental factors are classified with respect to their probability of occurrence and their impact on the firm's international business. Based on such assessment, a priority list of international business activities and their significant impact are assessed to avoid risk on investment and to benefit from changes.

\section{IMPACT OF DOMESTIC ENVIRONMENT :}

Impact of Domestic environment on International business decisions are depicted under following 5 categories :

(1) Economic Environment :

- Type of home country Economy - Firms from developed and high-income countries.

- Home country FDI policies - Countries foreign investment policies.

- Home country investors/shareholders perception on foreign investment. 
- Home country firms profit profile during last few years.

- Home country bank loan interest rate on firms foreign investment.

- Stability of home country currency exchange rates.

(2) Political Environment :

- Home country government support on foreign investment by firms for international investment decisions.

- Home country political stability to maintain a constant outbound foreign policy.

- Home country policy on encouraging foreign investment through low-interest rate on bank finance.

- Home country government policy on tax rates on foreign business profit and their reinvestment in the home country.

- Instability in home country government is expected to shake the economic condition of the home country and decrease the confidence of firms on their foreign investment.

(3) Socio-Cultural Environment :

- Home country cultural diversity and the experience of the firm on doing successful domestic business may improve its confidence in foreign investment.

- The experience of the firm on nature of purchasing habit of diversified people based on its product feature.

- Variation in local religion, demography, tradition of doing business leads improved business strategy in the local market and it can be transferred to foreign countries.

(4) Technological Environment :

- The quality of technology and its ability to automate business processes by firms leads lost cost business performance in the home country.

- High competition in local firms leads enhanced investment on $\mathrm{R} \& \mathrm{D}$ by local firms, which results in better technology in the domestic country.

- High tech supporting industries in a country leads a firm to develop better internationally acceptable products.
- Firms which have developed better technology want to earn more by expanding from domain business to foreign business.

- Simplification of business processes through the use of advanced technologies in the home country leads to low-cost player in home country which encourages the firm to earn more from foreign investment.

- Technology monopoly as well as earned patents for business processes in home country also stimulates the firm to invest and expand its business to foreign countries.

(5) The Legal Environment :

- A firm's experience in ethical business and success for sustainability in domestic environment.

- The nature of home country laws deals with the conduct of the firm in the domestic market and trade with third countries.

- The difficulty in regulations of local laws related to doing business may give enhanced confidence in the foreign business expansion.

\section{IMPACT OF FOREIGN} ENVIRONMENT:

Impact of foreign environment on International business decisions are depicted under following 5 categories :

(1) Economic Environment :

- The economic level of the foreign country based on per capita income/GDP.

- The current level of inflation in the prospective country and what is its forecast.

- Current exchange rates between home and host countries and possible future variations.

- The long-term prospects for the host country's economy, gross domestic product (GDP) per capita, and other economic factors.

(2) Political Environment :

- The host country government policies for easy FDI money transfer, and simplifying the permissions for construction of manufacturing facilities for foreign investors.

- The supportive nature of the political atmosphere in the host country to the foreign firm's investment, their business, the employment creation to the locals, etc. has an impact on firm's decision. 
- The stability of the host country government gives security for the foreign firms in terms of changes in business policies towards foreign investors \& permissions.

(3) Socio-Cultural Environment :

- The population and the educational level of the people in the host country.

- The set of values, beliefs, rules, and institutions held by a specific group of people in the host country society.

- The significance of socio-culture in deciding consumer attitudes, lifestyle, and behaviour of the host country on firm's decision.

- The attitudes of the consumers on foreign products and services.

- The dominant religion and its support for the sales of firm's products.

- The impact of host country language upon the diffusion of products onto markets.

- The roles of men and women within society and its impact on firms production/marketing in the host country.

- The opinion of people of the host country on environmental and green issues.

(4) Technological Environment :

- The advanced technology owned by foreign firm makes its products and services to be made more cheaply and to a better standard of quality.

- The advanced technologies possessed by the foreign firms offer consumers and businesses more innovative products and services.

- Impact on the distribution of products and services on customers in host country due to firms advanced distribution technology.

- Use of advanced technology by the foreign firms in a new way to communicate with consumers.

(5) The Legal Environment :

- Foreign companies usually face a number of regulations in host countries which include investment regulations, tariffs and duties, antidumping regulations and the protection policies of local industries.

- In many host countries, the laws for foreign firms are designed either to exclude them from competing with domestic firms in certain sectors or their involvement in many industry sectors is severely restricted.

- Tariffs and duties are used by the host countries to discourage importation of nonessential products in order to conserve foreign exchange and maintain a favourable balance of trade.

\section{IMPACT OF GLOBAL ENVIRONMENT:}

Impact of global environment on International business decisions are depicted under following 5 categories :

(1) Economic Environment :

- The impact of the economic conditions of the people of the entire world has a considerable effect on the business performance of the global firms.

- The per-capita income of the people of the entire globe decides the business sustainability of the global firms in any country.

- The natural and acquired endowments of the countries also in a continent decide business opportunities and the profit structure of the international firms.

(2) Political Environment :

- The global political environment also affects the international business investment decisions of the firms due to the fact of the inter-dependent economy.

- The process of globalization through decreased cross-border trade restrictions made the economy of the entire globe as inter-dependent.

- The political unrest in any part of the world or any kind of natural or manmade distortion will affect the share market and GDP of the entire world.

(3) Socio-Cultural Environment :

- The demand for various products and services in a global context where the production spreads on several countries.

- The perception of people in any country on foreign product and services has an impact on the decision of international firms to customize their products or services as per local/domestic needs.

- Fast changes in unique cultures and traditions of the countries and integration of them into 
global culture (unification of culture) has both positive and negative impact on the decision of the firms in international business investment.

\section{(4) Technological Environment :}

- The effect of anticipated breakthrough technologies on international business practices and decisions has a major role and perhaps has continued effect due to many firms involvement to develop such technology at international level.

- Technological leadership is achieved by many multinational companies through continuous innovation, research, and development by reserving a considerable part of their annual budget due to the reason that technological innovations are very costly but still profitable for long range.

- The impact of technology on employment, environment including clean \& green atmosphere are also issues of discussions.

(5) The Legal Environment :

- International laws are particularly relevant in areas relating to patents and trademark protective' and piracy laws, UN resolutions, multilateral trade agreements, and codes of conduct for multinational firms.

- Legal protection of intellectual property and patents in foreign countries through some international agreements.

- The status of employment, health and safety, and product safety laws for all stakeholders in the international business based on protective measures taken under such international agreements.

\section{CONCLUSION :}

The impact of domestic, foreign, and global environment on international business invest decisions are studied in this paper by providing a framework for analysing various business environments from the investor firms frame of reference. It is known that the international business investment is a risky process due to many unanticipated environmental changes and environmental factors which effects the successful management of the foreign business of a firm as sustainable for long time. Based on the objectives of the paper, the effect of domestic, foreign, and global environment on international business invest decisions are discussed in detail. The issues corresponding to the global environment for international business decisions can be analysed using four steps which include Global environmental Observation, Global environmental monitoring, and Global environmental assessment, Global environmental forecasting and Assessment of global investment outcome. This procedure of global environmental analysis allows firms to take optimum decisions in international business investments for sustainable profit. The impact of domestic environment, foreign environment, and global environment on International business decisions are also discussed under following five categories including economic environmental issues, political environmental issues, sociocultural environmental issues, technological environmental issues, and legal environmental issues.

\section{REFERENCES :}

[1] Aithal, P. S. (2017). A critical study on Various Frameworks used to analyse International Business and its Environment. International Journal of Applied Engineering and Management Letters (IJAEML), 1(2), 78-97. DOI: http://dx.doi.org/10.5281/zenodo.1053578.

[2] Dymsza, W. A. (1984). Trends in multinational business and global environments: a perspective. Journal of International Business Studies, 15(3), 2546.

[3] Welch, L. S., \& Luostarinen, R. (1988). Internationalization: Evolution of a concept. Journal of general management, 14(2), 34-55.

[4] Melin, L. (1992). Internationalization as a strategy process. Strategic management journal, 13(S2), 99-118.

[5] Riahi-Belkaoui, A. (1998). The effects of the degree of internationalization on firm performance. International Business Review, 7(3), 315-321.

[6] Blomstrom, M., \& Kokko, A. (2003). The 
economics of foreign direct investment incentives (No. w9489). National Bureau of Economic Research.

[7] Rugman, A. M., \& Verbeke, A. (2004). A perspective on regional and global strategies of multinational enterprises. Journal of international business studies, 35(1), 3-18.

[8] Held, D., McGrew, A., Goldblatt, D., \& Perraton, J. (2000). Global transformations: Politics, economics and culture. In Politics at the Edge (pp. 14-28). Palgrave Macmillan UK.

[9] Wan, W. P., \& Hoskisson, R. E. (2003). Home country environments, corporate diversification strategies, and firm performance. Academy of Management journal, 46(1), 27-45.

[10] Knight, G. A., \& Cavusgil, S. T. (2004). Innovation, organizational capabilities, and the born-global firm. Journal of international business studies, 35(2), 124141.

[11] Buckley, P. J., \& Ghauri, P. N. (2004). Globalisation, economic geography and the strategy of multinational enterprises. Journal of International Business Studies, 35(2), 81-98.

[12] Hitt, M. A., Li, D., \& Xu, K. (2016). International strategy: From local to global and beyond. Journal of World Business, 51(1), 58-73.

[13] Verbeke, A., \& Asmussen, C. G. (2016). Global, local, or regional? The locus of MNE strategies. Journal of Management Studies, 53(6), 1051-1075.

[14] Lee, H., Biglaiser, G., \& Staats, J. L. (2014). The effects of political risk on different entry modes of foreign direct investment. International Interactions, 40(5), 683-710.

[15] Bowen, H. P., Baker, H. K., \& Powell, G. E. (2015). Globalization and diversification strategy: A managerial perspective. Scandinavian Journal of
Management, 31(1), 25-39.

[16] Popescu, G. H. (2013). Macroeconomics, effective leadership, and the global business environment. Contemporary Readings in Law and Social Justice, 5(2), 170.

[17] López-Duarte, C., Vidal-Suárez, M. M., \& González-Díaz, B. (2016). International business and national culture: a literature review and research agenda. International Journal of Management Reviews, 18(4), 397-416.

[18] Liu, Y., \& Almor, T. (2016). How culture influences the way entrepreneurs deal with uncertainty in inter-organizational relationships: The case of returnee versus local entrepreneurs in China. International Business Review, 25(1), 4-14.

[19] Aithal, P. S. \& Shubhrajyotsna Aithal, (2015). Managing Anticipated Breakthrough Technologies of 21st Century-A review. International Journal of Research \& Development in Technology and Management Sciences, 21(6), 112 133, DOI http://doi.org/10.5281/zenodo.61617.

[20] Aithal, P. S. \& Preethi J., (2016). How Service Industries can Transform themselves into Green Business Industries, International Journal of Management Sciences and Business Research (IJMSBR), 5(4), 150-158. DOI : http://doi.org/10.5281/zenodo.161114.

[21] Aithal, P. S. and Shubhrajyotsna Aithal, (2016). Opportunities \& Challenges for Green Technology in $21^{\text {st }}$ Century. International Journal of Current Research and Modern Education (IJCRME), 1(1), 818-828. DOI http://doi.org/10.5281/zenodo.62020.

[22] Aithal, P. S. (2015). Concept of Ideal Business \& Its Realization using EBusiness Model, International Journal of Science and Research (IJSR), 4(3), 1267 1274. DOI http://doi.org/10.5281/zenodo.61648.

[23] Boddewyn, J. J., \& Brewer, T. L. (1994). 
International-business political behavior: New theoretical directions. Academy of management review, 19(1), 119-143.

[24] Zahra, S. A., \& Garvis, D. M. (2000). International corporate entrepreneurship and firm performance: The moderating effect of international environmental hostility. Journal of business venturing, 15(5), 469-492.

[25] Christmann, P. (2004). Multinational companies and the natural environment: Determinants of global environmental policy. Academy of Management Journal, 47(5), 747-760.

[26] Tihanyi, L., Griffith, D. A., \& Russell, C. J. (2005). The effect of cultural distance on entry mode choice, international diversification, and MNE performance: A meta-analysis. Journal of International Business Studies, 36(3), 270-283. 